\author{
BASIA NikIFOROVA \\ Lithuanian Culture Research Institute \\ E-MAIL: BNIKIFOROVA@HOTMAIL.COM
}

\title{
EUROPEAN BORDERS AND IDENTITY FROM THE NEW MATERIALIST APPROACH
}

Facts no longer have any trajectory of their own, they arise at the intersection of the models; a single fact may even be engendered by all the models at once

Jean Baudrillard

\section{Introduction}

The European border crisis integrates sociological, political, and philosophical analyses. The new materialist approach is one of the methods of interdisciplinary research. Scholars recently exploring "how matter comes to matter" call themselves new or neo-materialists. They implement radical interdisciplinary research based on the conviction that current economic, ecological, and political crises as well as technological advances and everyday practices do not allow the concept of "matter" as an object that could be captured along traditional disciplinary lines. New materialism is "new" in the sense that it is an attempt to leap into the future without adequate preparation in the present, through becoming, a movement of becoming-more and becoming-other, which involves orientation to the creation of the new, to an unknown future, to what is no longer recognizable in terms of the present. New materialism is widely used by policy makers who want to understand how it can possibly deal with current-day complexities pertaining to socio-political and cultural conflicts. Applying the new materialist approach, we analyze borders and borderlands from the perspective of space and time.

Borders and border regions are particularly revealing places for social research, especially in the present era of growing globalization, and the growth of the European Union. A Border is a place, a territory where "past" and "future" are permanently clashing. The "past" was never simply there 
to begin with, and the "future" is not what will unfold; instead, "past" and "future" are iteratively reconfigured and enfolded through the world's ongoing intra-activity. In the new materialists' view, the "past" is open to change: "it can be redeemed, productively reconfigured in an iterative unfolding of space, time, matter" [Interviews \& Cartographies 2012]. There is no inherently determinate relationship between past, present, and future on the border. History suggests that borders and borderlands are territories where the possibility to "repair" the "now" situation exists. These kinds of "diffraction patterns" are not simply reflections, they are not reflected in a specific place; instead, they produce changes in public consciousness. "The diffraction can be a metaphor for another kind of critical consciousness" [Interviews \& Cartographies 2012]. The massive ongoing refugee crisis in Europe is an example of such diffraction, which, in reality, not only is a concentration of current wars and conflicts, but also represents a long history of injustice, political and social mistakes.

The biggest European refugee crisis in 70 years atomized into a chaotic series of border confrontations and diplomatic disputes, as crowds of refugees were blocked from passing through a number of crossings in Central Europe, prompting the European Union to warn that the concept of European unity was at risk. Border controls appear to negate the most visible achievement of European integration. Today, the following announcements can be heard in Europe: "Schengen surely can't survive now" or "Bye-bye, Schengen". Theorizing about the crisis of the European border regime, many researchers have turned to a reassessment and reinterpretation of such definitions as colonialism and post-colonialism, racism, and post-racism. From Dimitris Papadopoulos' and Sanjay Sherma's point of view, racialized power is increasingly deterritorialized, and the transgression of extant borders is constitutive for their reproduction. Power is not simply a function of the symbolic, it is rather an operation of the "real".

\section{New actualization of European borders and borderlands}

During the last ten years, we have heard such a politically correct and tolerant formulation as "We welcome each and all immigrants irrespective of race or religion as long as they are willing to respect and accept our modern liberal secular European norms". At the moment, we are observing a different situation and diverse opinions. The present state is totalizing the discourse on illegal immigrants as an incomprehensible alien, radical, and absolute Other. At the same time, we see a paradoxical situation where 
humanitarian practices often lead migrants to dehumanizing and lethal border conditions.

At a very crucial and difficult time for the EU, irregular migration flows are forcing political debates over the functioning and effectiveness of the Schengen area. This situation brings us back again to discuss the tendencies in the dialectical process of the borders. Both Étienne Balibar and José Casanova are particularly influential researchers of European borders and identity. Ten years ago, José Casanova said that "most European countries still have difficulty viewing themselves as permanent immigrant societies or viewing the foreign born, and even the native second and third generation, as nationals, irrespective of their legal status" [Casanova 2004: 2]. He assumes that "one of the most significant consequences of the new immigration has been a dramatic growth in religious diversity" [Casanova 2004: 2]. To him, "contemporary debates across Europe illustrate a fundamental tension between cosmopolitan secularism and a kind of multiculturalism" [Casanova 2004: 9].

In Étienne Balibar's view, Europe itself is a frontier. He suggests that this representation of the border, essential as it is for state institutions, is nevertheless profoundly inadequate when taking account of the complexity of real situations, of the topology underlying the sometimes peaceful and sometimes violent mutual relations among the identities having constituted European history. In fact, Balibar discovered and made a list of some general features of European borders [Balibar 2004]. He remarks that in our political tradition territories combine the institutions of sovereignty and the government of populations in a single unity. The borders are no longer entirely situated at the outer limit of territories, they are somewhat dispersed in all directions, where the information, people, and things that are happening are controlled. Europe has always been home to tensions among numerous religious, cultural and linguistic identities, multiple readings of history. Balibar concluded that borders are starting to be a "transitional object", an object of permanent transgression, and European citizenship is a "citizenship of borders" in the metaphoric sense.

It is possible to investigate two opposite, reciprocal processes in the European territory: the disappearance and strengthening of borders. Deleuze and Guattari note the two general tendencies - "territorialization" and "deterritorialization" - which are very important for the philosophical analysis of borders today. Territorialization mostly means differentiation of space and construction of borders. Deterritorialization is described as the eradication of social, political, or cultural practices from their native places 
and populations. It means taking control and order away from a land or a place (territory) that is already established. As a result of this process, ties between ethnic, religious belonging, culture and place weaken. At the same time, both deterritorialization and territorialization are processes which are going on and developing not only in a physical territory, but also in a psychological territory which designates the status of the relationship between groups or individuals. Felix Guattari differentiates the process of deterritorialization into "relative" and "absolute" deterritorialization. To him, relative deterritorialization constitutes the possibility of re-territorialization or returning to a past situation. Absolute deterritorialization is marked by the impossibility of being territorialized again. Deterritorialization tends to be followed by re-territorialization [Deleuze, Guattari 1994: 110].

\section{The time of border strengthening}

After some decades of European "deterritorialization", we are observimg a tendency toward the process of re-territorialization. Today is a time of re-territorialization. According to the European border agency Frontex, approximately 340000 immigrants arrived in the European Union countries in the first seven months of 2015. Most of them crossed the South European border. European Union officials are searching for a common migration policy. The South European borderlands are becoming a true social and political laboratory. This leads to paradoxical situations such as humanitarian policies and practices often exposing irregular migrants to dehumanizing and lethal border security mechanisms. The dominant way of understanding these dynamics, one that blames the gap between policy and practice, fails to address the deeper political issues at stake and ends up perpetuating the terms of the crisis.

This situation was not unknown to 20th century Europe. The continent has coped with emergencies several times in the past. The first appearance of refugees as a mass phenomenon occurred at the end of World War I when the Russian, Austro-Hungarian, and Ottoman empires collapsed, and the new order created by the peace treaties profoundly upset the demographic and territorial structure of Central and Eastern Europe. A similar, though more tragic situation unraveled after World War II when millions of people started moving from their own countries. The Balkan wars of the 1990s generated vast refugee flows that Germany and other countries were able to manage. France accepted around 100000 people after the end of the 
Vietnam War. However, the case of the 21st century is not the same. It is different in view of its mass, chaotic, and unforeseen nature.

In this difficult situation, some Eastern European countries are starting to have special demands or atavistic concerns such as "we want only Christian refugees" (Slovakia) or "we are the last defender of European values in the face of an invasion by people from 'different civilizational roots"' (Hungary). Eastern European countries fear that outsiders will bring unwelcome values and habits with them, which will cause the appearance of crime-ridden segregated cities like Malmo in their countries, and struggle against the future they wish to avoid. After the Paris terrorist attack, Angela Merkel's words about the migrant crisis, giving it the name of "the next great European project", looked doubtful and too optimistic.

A new approach for analysis of the European border crisis is offered by Nick Vaughan-Williams. In his book, "Europe’s Border Crisis. Biopolitical Security and Beyond", he puts forward an alternative diagnosis of the problem in order to move beyond the present impasse. He argues that both the negative and positive dimensions of EU border security are symptomatic of tensions within the biopolitical techniques of states and their government. "While bordering practices are designed to play a defensive role, they contain the potential for excessive security mechanisms that threaten the very values and lives they purport to protect" [Vaughan-Williams 2015]. The book draws on different biopolitical keys to interrogate diverse technologies of power at a range of border sites and explore the insights and limits of the biopolitical paradigm. He asks difficult questions, which have no simple answers: must border security always result in dehumanization and death? Is an affirmative approach to border politics possible?

Vaughan-Williams suggests that today we have a crisis of humanitarian critique, conceptual crises in critical border and migration studies. To him, the current situation implies a necessity to re-actualize and rethink the approaches to the border as an immune system (Esposito) and a biopolitical as well as zoopolitical complex (Derrida, Agamben). Vaughan-Williams writes: "I argue that the animalisation of 'irregular' migrants constitutes a specific spatial technology of power that neither Foucaultian biopolitics nor Agambenian thanatopolitics - two prominent frames mobilized within critical approaches to border security and migration - can adequately grasp" [Vaughan-Williams 2015: 4]. It is important to note that, more than 70 years ago, Hannah Arendt suggested that "the concept of the rights of man based on the supposed existence of a human being as such, collapsed 
in ruins as soon as those who professed it found themselves for the first time before men who had truly lost every other specific quality and connection except for the mere fact of being humans" [Arendt 1996].

Nowadays, the anthropocentric frame of understanding biopower includes such terminology as "man-as-species", Giorgio Agamben's "anthropological machine" and the figure of "Homo Sacer", and the Derridian "zoopolitical border". At the same time, "irregular" populations at the border account for all characteristics closely associated with what Michel Foucault has referred to as biopolitics [Foucault 2003; 2007; 2008]. To Foucault, the developments, political and social changes brought about by industrialization and demographic growth, have created the concept of sovereign power which represents "the right to take life or let live" [Foucault 2003: 241; 2008].

Today, it is utterly important to understand the mass phenomenon of refugees on the theoretical level, because they are a subject of persecution, displacement, loss and suffering. Nevertheless, given the shifting circumstances of present-day refugees, it is necessary to mention that the case is not completely the same in the 21 st century. As Frances Daly remarks, "drawing out the radical consequences of phenomena such as 'exodus' and the existence of the refugee is crucial, but the context of this cannot be ignored. This is all more the case if the shift that Giorgio Agamben would have us think possible is to take place - to a generalized acknowledgement that we are all refugees" [Agamben 1995: 119; Daly 2004]. In the essay "We Refugees", Agamben suggests that instead of looking at Europe as an impossible "Europe of nations", whose catastrophic results can already be perceived in the short term, we could perceive it as an extraterritorial space in which all residents of the European states would be in a position of exodus or refuge, and the status of a "European" would mean a "citizen being-inexodus". The European space would thus represent an unbridgeable gap between birth and nation, in which the old concept of people could again find a political sense by decisively opposing the concept of nation [Agamben 1995].

Analyzing the contemporary discourse of the sacred, Giorgio Agamben reveals the concept of "Homo Sacer" ("Holy Man") which comes from Roman law (a person convicted of a crime can be killed but not sacrificed during a ritual). The concept of "Homo Sacer" describes the basic relation between the biological fact of human life and sovereign power which is the main form of political existence. In the crisis, the ambivalence of European borders becomes a general dimension of today's politics. 


\section{Once again on Derrida’s “unconditional hospitality"}

Analyzing Jacques Derrida’s "unconditional hospitality" concept, we should remark that one of the very important political actors being strongly actualized today is the Other. In his political philosophy, Derrida concentrates on what happens when people, excluded from any system of politics or law, present themselves and ask for refuge or justice. During the last years, one of the major issues in philosophy has been the question concerning the Other: how and to what degree are we able to receive and welcome the Other as the Other is?

The question is concerned with our hospitality, with our willingness and capability to offer the Other a welcome. This debate is of great importance today. Some obvious examples are terrorism (the last attack in Paris) and the debate on mass immigration. Around 20 years ago Jacques Derrida constructed his own concept of unconditional hospitality on a radical base. In the discussion "Politics and Friendship", the root of the problem is said to be in our relation to the Other. We have to keep it open or try to keep it open unconditionally - "I open my space, my home, my language, my culture, my nation, my state, and myself". At the same time, we have to solve the problem of negotiating the connection between this unconditional hospitality and the necessary conditions to organize this hospitality, which include regulations, rights, conventions, borders, laws on immigration. However, Derrida remarks that the attempt to re-define hospitality not only in terms of the nation-state but also in the cosmopolitan view is regarded by many as a utopian or very distant perspective. "Hospitality is a very general name for all our relations to the Other, has to be re-invented at every second, it is something without a pre-given rule" [Derrida 1997].

Derrida understood all the consequences of hospitality: being hospitable is not an easy obligation. The problem lies in the disharmony between two laws: the law of unconditional hospitality and the laws of hospitality. Derrida's examination of the conflict between the law of hospitality as such and the laws of hospitality (the norms, duties and laws of a society that form the basis of hospitable habits) makes visible all the difficulties of the realization of this project. Derrida's reflection suggests that it is not about finding eternal answers, but rather about being open to insecurity in the decision concerning hospitality. In other words, hospitality has to be reinvented all the time, demanding a responsibility towards the Other.

Welcoming the Other in the form of codified tolerance implies the conditional welcoming and hospitality which are limited within law and 
legislation. Derrida realized the potential controversy of this situation and noted, "I say not as a rule, but sometimes, exceptionally, it may happen. I cannot regulate, control or determine these moments, but it may happen, just as an act of forgiveness, some forgiveness may happen, pure forgiveness may happen. Unconditional hospitality can't be an establishment, but it may happen as a miracle in an instant, not lasting more than an instant, it may happen" [Derrida 2001: 15-16]. Derrida used the verb "may" repeatedly. $\mathrm{He}$ spoke of possibility rather than reality; potentiality rather than necessity. Derrida believes that it is only faith in the possibility of the impossible that must guide our decisions. Derrida's American interpreter, John Caputo, wrote, "His passion is not a determinable wish or will for a definable goal or foreseeable objective... It is not a search for something plannable and foreseeable, the fulfillment of which can be steadily approximated..." and "Derrida tells us that while religion, like law, is deconstructible..., for him, to speak to another is to ask the other to 'believe in me' or 'trust me'. Such faith, says Derrida, is 'absolutely universal.' This universal structure of faith is an undeconstructible that Derrida calls the messianic structure or messianicity" [Caputo 1997: 333].

\section{Public European discourse on religion, civilization and race identities}

On the ground of globalization, religious pluralism and intensified Muslim religious and cultural factors, some changes can be observed in the sense and structure of European identity. The EU represents a system of values that links peoples and nations together and provides them with identity. European identity is not a static and final situation but a dynamic, open process, in which the members of European society agree on common perceptions of themselves and others. A structuralist paradigm of European identity means that an orientation to Europe derives fundamentally from association with other Europeans. Identity arises from interacting with others and coming to the realization that one has much in common with them. Europe is not only a place or a particular territory, but, above all, an ability and mode of cultural communication. In every society, immigrants were and are a source of cultural and religious differentiation. Religion has also been seen as a historically and contemporarily important facet of the cultures of people arriving in Europe. Values start to be a more powerful source of demarcation. This differentiation is connected with the situation in which the potential sources of immigrants are culturally distinct from traditional European cultures, values, and perception of democracy. Among 
the more appreciable distinctions are relations between the individual and a group (family), the social status of a woman in a family, and public demonstration of religious beliefs which are centered on patriarchal religious law.

In the current situation, a sharper perception of Europe is gradually appearing, and that is a Christian one. At the same time, demarcation of identity comes through one's racial belonging. Identity polarization is evolving in two directions: from its weakening and erosion in the traditional sense to its reinforcement and emergence of new, previously less meaningful or even dormant elements, such as continental and racial belonging.

Historically, there has been an intense debate over the issue of race as a social construct versus race in the biological sense. Nowadays, the concept of "race" is mostly accepted as a social construct as opposed to the biological fact. The notion of racialization has developed over time. In the book "Racism", the sociologist Robert Miles described racialization as "a dialectical process by which meaning is attributed to particular biological features of human beings, as a result of which individuals may be assigned to a general category of persons which reproduces itself biologically. ... The process of racialization of human beings entails the racialization of the processes in which they participate and the structures and institutions that result" [Miles 1989: 76].

At the end of the 20th century, among the ways to perceive this social race construct as an epistemological problem, the following outlook gained popularity: "If we banish the concept of 'race' from our mentality, we abolish racism", "Race is the kind of category about which no one is neutral" [Haraway 1997: 213]. Indeed, simply ceasing to talk of "race" does not negate the effects that it produces. However, it is only one side of the problem. As Amy Gutmann points out, "identity groups are politically significant associations of people who are identified by or identify with one or more shared social markers. Gender, race, class, ethnicity, nationality, religion, disability, and sexual orientation are among the most obvious examples of shared social markers, around which informal and formal identity groups form" [Gutmann 2003: 8].

Today it is evident that deconstruction of European identity can spread in the direction of consolidation of majority and minority groups, as Western civilization represents both the growth of xenophobia and intolerance. The totalizing discourse on illegal immigrants as essentially non-civilized, fundamentalist, illiberal and undemocratic is starting to become a part of the media's public political vocabulary. We observe how the "exceptional" 
practice of detention has become a routine method to control "irregular" mobility throughout EU borderlands.

Depersonalization has started to be a part of rhetoric in both politics and media but "words are not just words". Such turns of speech as "swarm of people", "anchor babies", "crude person", "flooded by the rising tide of refugees" are used in disturbing contexts.

Recommendation 97 (20) by the Committee of Ministers of the Council of Europe gives a definition of the "hate speech" concept as follows: "the term 'hate speech' shall be understood as covering all forms of expression which spread, incite, promote or justify racial hatred, xenophobia, anti-Semitism or other forms of hatred based on intolerance." Reduced sensitivity to public expressions in the mass media is one of the now-present symptoms that cause anxiety.

\section{Conclusion}

In the new materialists' view, the "past" is open to change. On the border there is no inherently determinate relationship between past, present, and future. History suggests that borders and borderlands are territories where the possibility to "repair" the "now" situation exists. "Diffraction patterns" are not simply reflections, they are not reflected in a specific place, but, instead, they produce changes in public consciousness. The ongoing massive European refugee crisis is an example of such diffraction, which represents the concentration of current wars, conflicts, and the long history of injustice and political mistakes as well. It is clearly visible that the concept of security remains in tension on both the human and state level.

Theoretical understanding of the mass phenomenon of refugees and migrants is important from the perspective of political, moral, and social "reparation now". Researchers offer different ways for an alternative diagnosis of the problem in order to move beyond the present impasse. They argue that both the negative and positive dimensions of EU border security are direct consequences of such tendencies as biopolitical techniques, thanatopolitics and a "zoopolitical border". They state the conceptual crisis of the humanitarian critique, critical border, migration and post- as well as neo-colonialism studies. Jacques Derrida's concept of "unconditional hospitality" should be analyzed again as a humanitarian message and password to the past which is open to change. The growth of totalizing discourse on illegal immigrants, intolerance, and depersonalization, is starting to be a part of the media's public political vocabulary. 


\section{Bibliography}

Agamben G. (1995), We Refugees. "Symposium”, t. 49(2), p. 114-119. Available from: http:// www.ranadasgupta.com/notes.asp?note_id=18

Agamben G. (1998), Homo Sacer: Sovereign Power and Bare Life. Stanford.

Arendt H. (1996), We Refugees, Altogether Elsewhere. Writers on Exile, edited by Marc Robinson, Washington.

Balibar E., 'Europe as Borderland', The Alexander von Humboldt Lecture in Human Geography, University of Nijmegen, Netherlands (November 10, 2004), p. 38-42. Available from: www.ru.nl/socgeo/colloquium/Europe\%20as\%20Borderland.pdf

Caputo J. (1997), The Prayers and Tears of Jacques Derrida, Bloomington and Indianapolis.

Casanova J. (2005), Immigration and the New Religious Pluralism: A EU/US Comparison (Paper presented at the Conference on "The New Religious Pluralism and Democracy”, Georgetown University, April 21-22, 2005). Available from: http://www.ipri.pt/ eventos/pdf/Paper_Casanova.pdf

Daly F. (2004), The Non-citizen and the Concept of Human Rights. "Borderlands", t. 3, nr 1. Available from: http://www.borderlands.net.au/vol3no1_2004/daly_noncitizen.htm

Deleuze G., Guattari F. (1994), What is Philosophy?, London, New York.

Derrida, J. (1997), Politics and Friendship: a Discussion with Jacques Derrida. Edited by G. Bennington. Centre for Modern French Thought, University of Sussex. Available from: www.sussex.ac.uk/Units/frenchthought/derrida.htm. Discussion with Jacques Derrida. (2001). An Exchange between Jacques Derrida and Sydney seminar participants. “Theory and Event”, issue 5.1, p. 15-16. Available from: https://muse.jhu.edu/ journals/theory_and_event/toc/tae5.1.html

Derrida J. (1998), Hospitality, Justice and Responsibility: A Dialogue with Jacques Derrida. In: Questioning Ethics: Contemporary Debates in Philosophy. Edited by R Kearney and M Dooley, London.

Dolphijn R. and Van der Tuin I. (2012), New Materialism: Interviews \& Cartographies. Open Humanities Press. An imprint of MPublishing - University of Michigan Library, Ann Arbor

Foucault M. (2003), Society Must Be Defended: Lectures at the Collège de France, 1975-1976, New York.

Foucault M. (2007), Security, Territory, Population: Lectures at the Collège deFrance, 1977-1978 , Basingstoke.

Foucault M. (2008), The Birth of Biopolitics: Lectures at the College de France, 1978-1979, Basingstoke.

Gutmann, A. (2003), Identity in Democracy. Princeton, New Jersey.

Haraway D. (1997), Modest_Witness@Second_Millenium.FemaleMan@_Meets_OncoMo$u_{\text {se }}^{\mathrm{Tx}}$ : Feminism and Technoscience. London, New York.

Miles R. (1989), Racism. London: Routledge, Vaughan-Williams, N. (2015), Europe's Border Crisis: Biopolitical Security and Beyond Oxford, Oxford. 


\section{SUMMARY}

\section{European borders and identity from new materialist approach}

The article deals with the concept of "new materialism" and tries to explain "how discourses come to matter" and "how matter comes to discourses" [Barad 2003, 2007]. Borders and border regions are particularly revealing places for social research, especially in the present era of growing globalization, growth of the EU and mass immigration. Two opposite, reciprocal processes are open for investigation on the European territory: disappearance and strengthening of borders. Analyses of the Derridian concept of "unconditional hospitality" and the new materialism discourse will provide a possibility to describe identity deconstruction. Jacques Derrida analyzed the limits of the contemporary socialpolitical concepts that have challenged European existence in the recent years. His political philosophy concentrates on what happens when people, excluded from any system of politics or law, present themselves and ask for refuge or justice. After the long years of "deterritorialization", today we observe such tendency as the process of re-territorialization. The author examines the public European discourse on religion, civilization and race belonging as a mark of European identity deconstruction.

KEYWORDS: border, deconstruction, identity, immigration, hospitality, new materialism 